\title{
EXPLORING E-PARTICIPATION POLICY AND INITIATIVES IN MALAYSIA
}

\author{
Nur Rusydina Khadzali ${ }^{1}$ \\ School of Government, College of Law, \\ Government and International Studies, \\ Universiti Utara Malaysia, 06010 Sintok, Kedah, Malaysia. \\ (E-mail: nurrusydina @gmail.com) \\ Zainal Md Zan ${ }^{2}$ \\ School of Government, College of Law, \\ Government and International Studies, \\ Universiti Utara Malaysia, 06010 Sintok, Kedah, Malaysia. \\ (Email: zainal@uum.edu.my)
}

Received date: $15-07-2019$

Revised date: $24-07-2019$

Accepted date: 03-09-2019

Published date: 05-09-2019

To cite this document: Khadzali, N. \& Md Zan, Z. (2019). Exploring E-participation Policy and Initiatives in Malaysia. International Journal of Law, Government and Communication, 4(16), 10-25.

DOI: $10.35631 / \mathrm{ijlgc.} 416002$

\begin{abstract}
The evolution of Information and Communication Technology (ICT) and the internet have affected the cultural, social, economic and political aspect throughout the world. It also greatly reshaped public administration in the last decade. The availability of internet and electronic medium also open the huge opportunity for public to participate and became closer to the government. New form of two-way communication for public and government officials have been developed and changed the landscape of local democracy. Consequently, in current digital era, the electronic participation or as known as eparticipation as tools that encourage public participation has gained increasingly important. With the complexity of modern society today, e-participation helps to enhance the quality of participation. E-participation also could be the great complement to the traditional approach of public participation that may have some significance limitation in empowering the public participation. However, the discussion on the e-participation policy and initiatives in Malaysia still lacking and remains unclear. Therefore, this paper aims to comprehensively deliberate on the efforts that have been taken by the government towards the e-participation implementation. This paper also will provide an example of the experiences on the world's best leaders in e-participation.
\end{abstract}

Keywords: e-democracy, e-participation, policy, initiatives, Malaysia 


\section{Introduction}

Over the last years, the professionals and experts became increasingly concern in researching on the public participation. Robert Putnam, the proponent in public participation believe that public participation is one of the essential requirements that lead for a better democracy and better society (Wallace \& Pichler, 2009). King, Feltey and Susel (1998) further assert that decision making without public participation is ineffective. Participation in democratic society for most of the people, perceived as limited only in the voting process for choosing their elected representatives However, participation is far beyond voting or campaigning (Nagel, 1995). In the meantime, people in various countries are not satisfied by just being a part of the voting process but they are also demanding a more active role in democratic process (Tambouris, Liotas, Kaliviotis, \& Tarabanis, 2007). As people become well-informed about various issues through media, they have become highly concern regarding the decisions made on their behalf. Over the last decade, the Information and Communication Technology (ICT) have massively increased the amount of information available and the speed at which it is transmitted. The arrival of the internet has renewed the debate on public participation. It also changes how we communicate, how we interact across the world and change our social norms. Currently, the internet creates a remarkable opportunity for the users in various aspect of life because everything now just at our fingertips (Hochtl, Parycek, \& Sachs, 2011). Yet, despite technological advances, there are still relatively few opportunities for the public to actively participate in decision making. Furthermore, the existing public participation mode such as voting, protest activities, lobbying and public meetings, are inadequate or less ideal to support the democratic standard within the current $21^{\text {st }}$ century era. Moreover, public participation field has been recently enhanced with the adoption of the ICT thus leading to electronic participation or as known as e-participation (Bryan, Tsagarousianou and Tambini and Friedmann as cited in Tambouris et al., 2007). E-participation aims to support the notion that the latest technology development could help to promote an active citizenship by increasing access and availability of participation in order to encourage fair and efficient relationship between society and government (Sæbø, Rose \& Flak, 2008).

In line in today's world, the e-participation is a necessity for the public and have the potential to be a strong medium for a democratic decision making. The field of e-participation is currently a rapid evolving one and catch the interest of many academicians and researchers. Therefore, there is various considerable research that contribute to a better understanding on the complexity of e-participation such as tools, techniques, framework, process and prospects (Wirtz, Daiser \& Binkowska, 2016; Mohamad Aizi, Shahizan, Mohd Farhan \& Azizul Azhar, 2012; Mohamad Aizi, Shahizan \& Mohamad Syakiran, 2011a; 2011b; Chee \& Atreyi, 2008; Tambouris et al., 2007; Macintosh, 2004), challenges, benefits, evaluation and impact of the implementation (Kim \& Lee, 2012; Macintosh, 2004) as well as initiatives and adoption by public local authorities Panopoulou, Tambouris, Nielsen, Zotou \& Tabaranis, 2011; Sobaci, 2010; Nachmias \& Rotem, 2007). However, among these emerging area, one relatively unexplored topic is the government's initiatives that have been practically implemented. According to Pratchett, Durose, Lowndes, Smith, Stoker and Wales (2009) the extensive existing literature on e-participation generally focusing on the normative discussion related to the potential and booster of the e-democracy in descriptive manner than the example of the use of internet for the policy deliberation practically. Consequently, the case based evidence quite limited. Kubicek and Aichholzer (2016) further asserts that the existing evaluation on eparticipation revealed that the comprehensive empirical evaluation practice is still lacking.

In the meantime, in the Malaysian context, it has been noticeable that e-participation study especially on the government effort and adoption is lacking compare to other leading 
countries. Mohamad Aizi et al. (2011a) in their study verifies that government organizations in Malaysia do not promote e-participation concept, to be precisely, lack of knowledge and collaboration effort. Therefore, we believe that the aspect of e-participation adoption and practices is remains unclear. With this in mind, consequently, the objective of this study is explore the policy and initiatives that have been implemented by the government. Hence, this study aims to systematically (i) examine the e-participation policy and initiatives that have been implemented by the top leading countries in e-participation as an example; (ii) examine the e-participation policy and initiative within Malaysian context; (iii) discuss on the context of e-participation policy and initiatives in Malaysia that differ from Denmark and Finland as an example of the leading countries in e-participation implementation and (iv) suggest the direction for future study. Even though this study is a non-empirical study, nevertheless it is significantly contributes to filling these missing area of e-participation for public to know, acknowledge and understand.

\section{Methodology}

This study is a library-based study that relied on the content analysis from various source including journal articles, books, government website and reports. The review started by highlighting the main theory of public participation that help to provide the readers with the basic concept and understanding which significantly grows to contribute for a comprehensive explanation on the context of public participation. Then, the e-participation performance between countries and followed by the e-participation initiatives that implemented varying across countries. Afterwards, the successful experienced from the top leading countries in eparticipation was also been studied. Subsequently, the e-participation policy and government initiatives that underlined particularly in Malaysia was explored. Then, the relevant literature that obtained systematically organized using the conceptual analysis by breaking down the concepts into their fundamental parts. However, as our prior work have been discussed on the history of public participation and various layers of context and background of e-participation (Nur Rusydina \& Zainal, 2018) therefore, this paper will not further include any fundamental elements of e-participation for the reader's understanding. This paper will straightforward highlight the policy and initiative of the government within Malaysian context and explore some of the example on e-participation best practices from the top performers as a desirable model.

\section{Arnstein's Ladder of Citizen Participation}

There is quite in number in term of the theory of public participation and one of the important theories can be referring to is Arnstein (1969) called the ladder of public participation. This theory essentially highlights about hierarchy of power within the society and how the public interact with each other. This concept appears in 1960's in America. At that time, the concept of the hierarchical society that implemented in America still was not being acknowledge and disregarded in other part of the countries. It is even worst when the people who are responsible in represent the public's opinions are ignore on the underlying principles of the concept. Arnstein presents eight level of participation that then divides into three different degree of participation which involves non-participation, tokenism and citizen power. As shown below in Figure 1, the non-participation level involves the first two level namely manipulation and therapy. This level is substitutes for genuine participation because, the real objective is not to enable people to participate in planning or conducting programs, but to enable power holders to educate or cure the participants. In other words, those in power remain their power to demonstrate the use of citizen participation. Meanwhile in the third and fourth level which is informing and consultation, its progress to levels of tokenism that allow the have-nots to hear and to have a voice. They are offered by power holders as the total 
extent of participation, citizens may indeed hear and be heard. But under these conditions they lack the power to ensure that their views will be heeded by the powerful. When participation is restricted to these levels, there is no assurance of changing the status quo. Furthermore, in the fifth level which is placation level, it is simply a higher level tokenism because the ground rules allow have-nots to advise but retain for the power holders the continued right to decide. Further up the ladders are referring to the participation level whereas levels of citizen power with increasing degrees of decision making clout. Citizens can enter into the partnership level that enables them to negotiate and engage in trade-offs with traditional power holders. At the top most, in the level of delegated power and citizen control, have-not citizens start to obtain most decision-making seats or full managerial power (Arnstein, 1969). Although this is an old concept, still it is very much valuable as a references and guidance in the field of public participation. Overall, Arnstein's theory shown that public participation is not stagnant, but it is a transformational process. However, the question regarding in what context and in which rungs that the leaders delegate the opportunity to empower the public in participation always depend on the administrator. This is because, there will be a restriction on the debatable issues when involving the public. Therefore, this theory also very relevant to be reflect in the e-participation implementation.

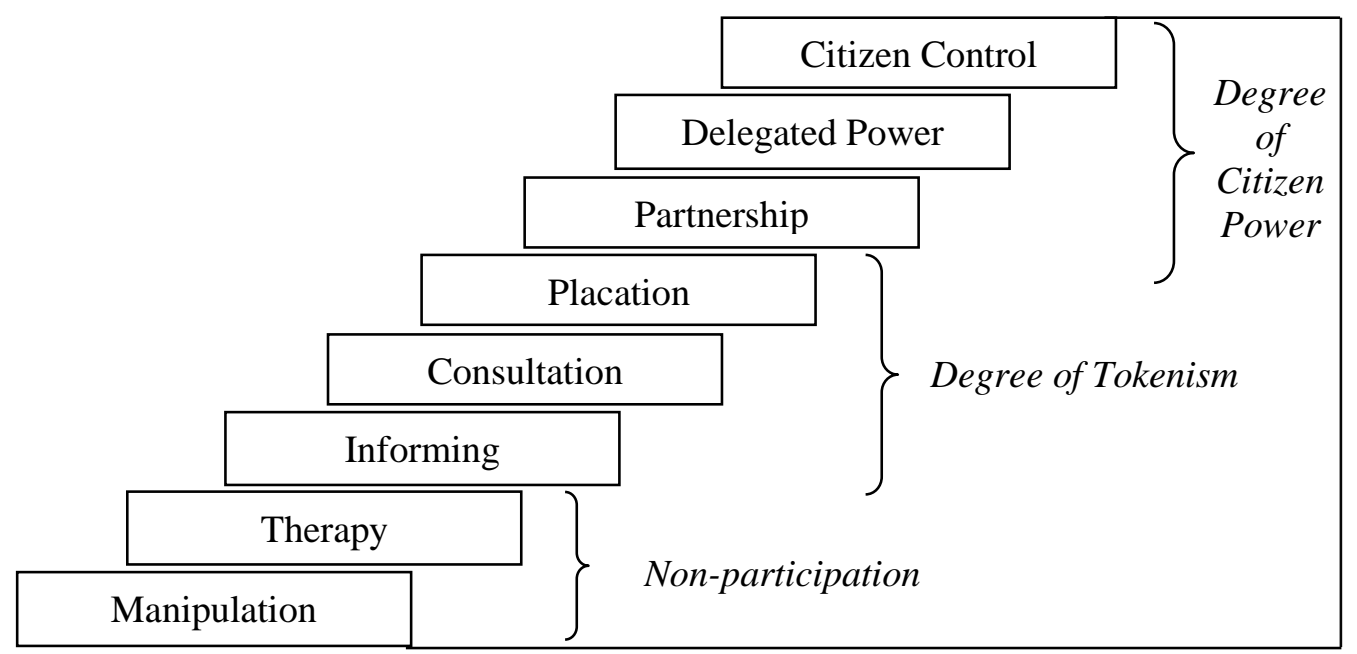

Figure 1: The Ladder of Citizen Participation

Source: Arnstein, 1969.

\section{E-Participation Performance between Malaysia and Others}

The e-participation performance of the country could be measured through the EParticipation Index (EPI). The EPI that provided by the United Nation refers to the government willingness to use the ICT in providing the high quality information and effective tools of communication for empowering public participation through consultations and decision making. In the simple term, EPI evaluate on how well the government had perform in connecting with their people. The EPI is measured based on three main elements consist of e-information, e-consultation and e-decision-making. In the 2018 survey, the result shown out of 193 countries, Denmark, Finland and Republic of Korea are ranked on the top as global leaders on e-participation among others. While, tagging along are Netherlands, Australia, Japan, New Zealand, United Kingdom, United States and Spain (United Nation, 2018). Table 1 had summarized the top ten countries that leading in e-participation.

Although Malaysia was not in the leading countries, but Malaysia performed better in 2018 by placed in rank 32 compare to 47 rank out of 193 countries in 2016 (United Nation, 2018; 
2016). The e-participation among Southeast Asia countries was led by Singapore and Philippines when both was in rank 13 and 19. Meanwhile Vietnam was in rank 72, Thailand in rank 82, Indonesia in rank 92, Brunei in rank 97, Timor Leste in rank 153, both Laos and Cambodia in rank 171 and Myanmar in rank 181. The United Nation (2018) was classified Singapore and Brunei as a high income country. While Malaysia and Thailand are upper middle income countries and others including Indonesia, Philippines, Vietnam, Laos, Cambodia, Myanmar and Timor Leste are low middle income countries. However, even though Brunei is a high income country, but based on the e-participation ranking and performances, it is in the lower rank compare to Malaysia. Whereas Philippines, the low middle income countries remarkably placed in higher ranking than Malaysia and Brunei.

TABLE 1: Top 10 E-Participation Performers

\begin{tabular}{|c|l|c|}
\hline Rank & \multicolumn{1}{|c|}{ Country } & Index \\
\hline 1 & Denmark & 1.000 \\
\hline 1 & Finland & 1.000 \\
\hline 1 & Republic of Korea & 1.000 \\
\hline 4 & Netherlands & 0.9888 \\
\hline 5 & Australia & 0.9831 \\
\hline 5 & Japan & 0.9831 \\
\hline 5 & New Zealand & 0.9831 \\
\hline 5 & Spain & 0.9831 \\
\hline 5 & United Kingdom of Great Britain and Northern Ireland & 0.9831 \\
\hline 5 & United States of America & 0.9831 \\
\hline
\end{tabular}

Source: United Nation, 2018.

\section{E-Participation Initiatives across Countries}

As the government worldwide realized the importance of e-participation, various initiatives across countries are implemented. The e-participation initiatives are varying across countries. It involves various governmental level either local, states or national level; various issues either political, law and policy making, budgeting, social or economic; and through various advanced platforms according to the preferences. Table 2 highlighted some of the example on e-participation initiatives that have been implemented in several countries.

Table 2: E-Participation Initiatives across Countries

\begin{tabular}{|c|c|c|}
\hline $\begin{array}{c}\text { Continent: } \\
\text { Country }\end{array}$ & E-Participation Initiatives & Description \\
\hline $\begin{array}{l}\text { Asia: } \\
\text { Israel }\end{array}$ & SHIL (http://shil.shil.info/) & $\begin{array}{l}\text { Establish by Welfare Ministry of } \\
\text { Israel and Information Society } \\
\text { Research Center in the University of } \\
\text { Haifa to provide the citizen with the } \\
\text { new communication channel in order } \\
\text { to communicate with the decision } \\
\text { makers in government agencies and } \\
\text { to improve the information flow } \\
\text { between public and authorities. }\end{array}$ \\
\hline
\end{tabular}




\begin{tabular}{|c|c|c|}
\hline $\begin{array}{l}\text { Asia: } \\
\text { Singapore }\end{array}$ & $\begin{array}{l}\text { REACH Portal } \\
\text { (http://www.reach.gov.sg) }\end{array}$ & $\begin{array}{l}\text { A national level consultation portal } \\
\text { that aims to encourage inputs from } \\
\text { the citizens regarding policy making. }\end{array}$ \\
\hline Australia & $\begin{array}{l}\text { Community Builder } \\
\text { (http://www.communitybuilders.nsw. } \\
\text { gov.au/) }\end{array}$ & $\begin{array}{l}\text { An interactive electronic clearing } \\
\text { house for the community level for } \\
\text { social, economic and environmental } \\
\text { renewal. It is used to enable the } \\
\text { online community consultation, e- } \\
\text { petition as well as to broadcast the } \\
\text { parliamentary activities. }\end{array}$ \\
\hline $\begin{array}{l}\text { Europe: } \\
\text { Denmark }\end{array}$ & Nordpol.dk (http://nordpol.dk) & $\begin{array}{l}\text { To enhance the citizen's interest and } \\
\text { knowledge in politics as well as to } \\
\text { strengthen the dialogue among the } \\
\text { citizens and politicians. }\end{array}$ \\
\hline $\begin{array}{l}\text { Europe: } \\
\text { Estonia }\end{array}$ & $\begin{array}{l}\text { TOM - Tana Otsustan Mina or } \\
\text { Today I Decide (http://tom.riik.ee/) }\end{array}$ & $\begin{array}{l}\text { To enhance citizens' participation in } \\
\text { policy making by allowing citizens to } \\
\text { comment of draft laws and submit } \\
\text { their own idea for new legislations. }\end{array}$ \\
\hline $\begin{array}{l}\text { Europe: } \\
\text { Italy }\end{array}$ & Iperbole (http://iperbole.bologna.it) & $\begin{array}{l}\text { An online civic network in Bologna } \\
\text { have been set up to widen the use of } \\
\text { the ICT, supply the information and } \\
\text { interactive services to the citizens of } \\
\text { Bologna and create an effective } \\
\text { dialogue between citizens and } \\
\text { government. }\end{array}$ \\
\hline $\begin{array}{l}\text { Europe: } \\
\text { Sweden }\end{array}$ & $\begin{array}{l}\text { Kalix Annual Consultation } \\
\text { (http://www.kalix.se) }\end{array}$ & $\begin{array}{l}\text { To engage citizen in a series of effort } \\
\text { to renew the town politics, including } \\
\text { the remodelling of the city center of } \\
\text { Kalix and tax issues. }\end{array}$ \\
\hline $\begin{array}{l}\text { Europe: } \\
\text { UK }\end{array}$ & $\begin{array}{l}\text { UK Government Consultations } \\
\text { (http://www.cabinetoffice.gov.uk/reg } \\
\text { ulation.aspx) }\end{array}$ & $\begin{array}{l}\text { Designed to facilitate the public } \\
\text { feedback on the policy issues and to } \\
\text { offer a useful political and civic } \\
\text { information to all the citizens. }\end{array}$ \\
\hline $\begin{array}{l}\text { North } \\
\text { America: } \\
\text { US }\end{array}$ & $\begin{array}{l}\text { Regulations.gov } \\
\text { (http://www.regulations.gov) }\end{array}$ & $\begin{array}{l}\text { A cross agency e-government effort } \\
\text { to transform the US's Federal rule } \\
\text { making process by enhancing } \\
\text { public's ability to take part in the } \\
\text { government's regulatory decision } \\
\text { making. }\end{array}$ \\
\hline
\end{tabular}

Source: Chee \& Atreyi, 2008. 


\section{E-Participation of Top Performers}

We have no intention to further discuss the initiatives that take place across countries as highlighted in Table 2. However, we had drawn the attention to focus only on the world's top performers in e-participation as best example. Therefore, in this section we explored on what have been done by the top two performers, Denmark and Finland.

\section{Denmark E-Participation}

Denmark had proved that their ambitious idea by digitalising most of the services had turn into a reality. As Denmark never failed to put themselves as the top leading countries in eparticipation had shown that the country's digital strategy as one of a key roles in every government's aspects are successfully implemented. Denmark Digital Strategies 2016-2020 take place every level of the government either central, regional or local government. There are tremendous initiatives that have been implemented in Denmark e-participation include:

\section{Strategic Interaction}

Denmark successfully implemented their digital strategy through strategic digital interaction between public sector and other different authorities. Denmark ensure that all sector and area that mostly complex and interrelated are possible for all through the digital platform. Digitisation successfully proved to be an effective and efficient tool in streamlining the processes and workflows in the public sector. In delivering an effective, efficient and strong services to all public and businesses, the strategic collaboration in digitisation among public sector require a continuous effort. In the meantime, public as an individual has a responsibility to understand the digital potential within its own care and ensure that digitisation leads to the desired change. In parallel with joint public sector efforts, there are sector-specific digitisation projects and strategies, for example joint municipal and regional digital strategies. This approach to public sector digitisation provides a good balance between common strategic targets and local adaptation and priorities. Additionally, strategic interaction between public sector with other sector such as private businesses, trade organisations and NGOs not only contributed in discovering the best mutual outcome for the digital evolution, but it is also contributed to protect a strong and secure digital foundation in Denmark (Agency for Digitisation, 2016).

\section{Digital ID}

Denmark had provided the digital IDs which called NemID for all the citizen to not only interact with the government, but also to access to other numerous services even within the private sector. Citizen can use their IDs to make the bank transactions, recover tax returns from the government portal and even to make an appointment with their hairdressers. Denmark also looking forward to personalizing the digital services by providing targeted content for citizens on their NemID portals. For example, citizens who nearly reached the age of retirement could log in their portal in order to review the retirement planning options that provided (Chia, 2018).

\section{Digital Post}

Denmark had shown the determination by introduced the digital self-service and digital post as a mandatory to all people as stipulated in the legislation (Perez, 2015). In the meantime, the officials in Denmark had proved that digitisation as a key driver in ensuring that the public sector is strong, accessible and citizen-orientated. Denmark made it mandatory by law to receive official letters online through a government-provided Digital Post account in 2013 for businesses, and in 2014 for citizens. Since November 2015, the country's Digital Post strategy attempt to ensure mandatory compliance, whereby citizens receive official 
communications from the public sector, digitally (Government Europa, 2018). Currently, there are 89 different service areas which is some of it are managed by local municipalities and some of it are provided by the central government. Through this, public could access to various services include the applications for health cards, maternity allowance, housing allowance, pensions and even to book for a campsite. All these self-services are available by the national citizen's portal. The government attempt to provide one platform that public could easily access to everything. As a result, in Spring 2015, nearly $80 \%$ of all transactions were performed by Denmark's digital self-service. Meanwhile, on $1^{\text {st }}$ November 2014, 97\% of citizens above the age of $15 \mathrm{knew}$ the digital post was going to happen and about $70 \%$ of citizens signed up for digital post before it became mandatory. Currently, for almost a year since Denmark introduced digital post, more than 60 million letters have been sent to citizens through online since $1^{\text {st }}$ January 2018 (Perez, 2015). Overall, it has been a tremendous success. Denmark have been quite surprised how their mandatory approach has been accepted in real life of their people and surprisingly to the elderlies. And today, all the people has been widely accepted that the digital communication as a main platform to communicate with the public authorities in Denmark and consequently, most of the Danish people are now using and receiving official letters digitally through the Digital Post (Government Europa, 2018).

\section{Digital Welfare}

Denmark had raised the standard for public digitisation through one of the remarkable initiatives by using the technology in care giving and medical aspect. These initiatives have been on the agenda for almost two decades. The social changes in the society such as an increasing number of ageing population, the chronic diseases and the limited financial resources had pressured the government to find new and efficient ways of providing the public services. Therefore, through the technology utilization in welfare services, it can make an important contribution in continuing the economic stability in Denmark as a welfare state. New technology and digital welfare solutions have already empowered elderly to live more autonomously and with greater quality of life. For example, telemedicine to patients with Chronic Obstructive Pulmonary Disease (COPD) has reduced costs and increased the sense of control and safety among the patients. This initiative not only provide the services to all public, but also create a better interconnection between public sector. The knowledge sharing across the public sector is important to ensure transparency and coherence amongst the citizen's proceedings. Better coordination between authorities and data sharing may also improve the course of treatments, when different stages of treatments are carried out by hospitals, general practitioners and the municipality (Agency for Digitisation, 2016).

\section{Other Digital Welfare Initiatives}

Under this initiative, Denmark had planned other six initiatives in digitising their services. However, two of the most important initiatives which involves; First, the dissemination of digital welfare solutions. This initiative aims to improve and accelerate the dissemination of documented and effective digital solutions in the health and social care area. A project within this initiative is telemedicine for women with pregnancy complications. This initiative provided the help to a woman with pregnancy complications through the medical equipment, which enables them to monitor themselves and submit the results to health professionals. This telemedicine helps them to feel safe and reduces their financial costs. Second, digitalising the learning and teaching processes. This initiative aims to provide an advance digital support in education. The technology that well utilized may contribute to the children's learning tremendously. The project within this initiative will help to ensure that relevant written exams in secondary school, specifically in the 8th and 9th grade exams, will be conducted digitally. 
Another project is an analysis of how common IT standards and infrastructure can support exchange of data to enable schools' digital platforms and digital teaching aids to interact (Agency for Digitisation, 2016).

E-participation in Denmark proof that e-participation is not impossible to be achieved. Nevertheless, it does not happen in a night because it required a continuous effort and a lot of hard work with full support by every level of government and people. However, the most important in Denmark's e-participation is no one was excluded. According to the Special Advisor to Denmark's Agency for Digitisation, Thomas Frandzen, as e-participation is part of the country's digital strategy and the mandatory digital interaction may seem an extreme approach, but the government ensure that citizens who could not access to the digital services are being helped. Frandzen further assert that the government could not accept if the people have to suffer for potentially life-threatening consequences or losing the rights to certain benefits, just because they are unaware or unable to check their digital post. Therefore, Denmark has been implemented a massive campaign and a huge awareness programme to the groups that they thought might have difficulties in using digital communications. Subsequently, a dialogue session has been taking place with various special interest groups which consists of the elderly organisations, disability organisations, networks, organisations working with immigrants, social housing groups and so on. Denmark remarkable digitisation initiatives not only beneficial to all the Danish people and other stakeholders but also expects to save the government expenditures up to $£ 200$ million a year (Perez, 2015). Denmark future strategy is to fully prepare their citizens, businesses and public sector employees for the digital Denmark of the future (Agency for Digitisation, 2016).

\section{Finland E-Participation}

In current digital age, Finland shown that their strong attitude in sustain the openness and democratic value are the key principle that being applied by Finland. These value and principle also practically applied through the Openness of Government Act that being reviewed in 1999. Openness and citizen participation have been actively developed during the last decades through various development program which involve the Government's Project Register (HARE) in 1999; the otakantaa.fi website in 2000; the Hear Citizens Project (2000-2005); the Government's Policy Program on Citizen Participation (2003-2007), the government portal of Finland as known as www.demokratia.fi and the on-going Democracy Network that established in 2007.

\section{The Government's Project Register (HARE)}

The government's project register provides the legal preparatory documentations on all public projects that implemented either by the government, parliament or ministries. All the necessary information and documentation on those projects could be reviewed by the authorities in the process of monitoring or evaluating the progress. Meanwhile, under the parliament and ministries as the service provider, the internet version of the project provides all the documents purposely to all the public. The information provided in this version mostly used by the ministries, state's administrative and public. Through this project, the government aim to be transparent and to be open with the public about all the project under the ministries. This project is one of the convenient tools that provide the public with all the information include the current project that take place under various ministries, the aims of the projects, the preparatory legal documents and report to the parliament, the committee and boards of the state enterprises and agencies, the working team or manpower that involve behind the projects, the progress of the projects, the relevant publications and the relationship 
with the government's programme related to the Finnish and European Union legislation. By the time the project finished, the related documents will be automatically transferred to the government archives and the register itself will generate a final report to be keep in archived. Public could use this platform without any charges, access code or username (Holkeri, 2002).

\section{The Otakantaa.fi Website}

The aims of otakantaa.fi website is to promote and enhance the dialogue and discussion between citizens and the public administrator on various topics. These include anything from drafting new laws to generating the needs and ideas for new policies. Public and other stakeholders could participate through provided tools such as polls and discussion. All the public's input and comment would be considered by the public administrator in future policy making. In the meantime, the consultations can be accessed through a website listing that sorted by the organisations that have initiated the consultations. This website is beneficial to everyone and can be accessed by large groups of stakeholders. It is a cost effective medium because it is fast and ease to be use. The participation methods and tools to support the consultation process also varied. In addition, it allows public to participate at anytime and anywhere, and it unify the consultation process within different organisations. The service has been acknowledged as one of the best practices by the Organization for economic Cooperation and Development (OECD) (Wilhelmsson, 2017).

\section{The Government's Policy Program on Citizen Participation (2003-2007)}

In addition, under the Finland national democracy project, Finland had launched the Government's Policy Program on Citizen Participation 2003-2007. The objectives of this program are to promote an active role of the society, to create a strong civil society through empower the public with the necessary influence and to have the effective functioning of representative democracy. Under this program, through the cooperation between civil society and research community with various ministries, several project on promoting public participation were implemented. This program is successfully increased the efficiency of civic and democracy education, improved the quality of communication between the citizen and the government, promote the democracy in municipal and improved functioning of municipal councils as well as evolution of the need for legislative policies. This program particularly focusing on strengthening the knowledge of democracy and organizing the significant information to the specific standard. The program formulated a plan for a democracy policy that will enable the government to promote social participation and influence by citizen as required by the Constitution of Finland (United Nation, 2018).

\section{The Government Portal Demokratia.fi}

Meanwhile, the government portal of Finland, www.demokratia.fi offers all the citizen to send any suggestion on the initiatives or commentaries to the national and local government. Through this portal that presented in Finnish and Swedish languages only, had launched one of the key services in the Citizen's Initiative for a legislative proposal in fall 2012. Over 50,000 people had signed on the initiatives within the specific time before it further referred to the parliament to be evaluated for any legislative changes or improvement. In 2015, the government through The Ministry of Finance initiated a project called HELP project that purposely to provide the necessary support those who are incapable or unaware in using the digital services. In the meantime, in order to ensure the diversity needs of different users are measured in accomplishing the goal to digitize public services, an Advisory Board called Digitalization of Everyday Life had been set up. This board that consists over 20 members are represented by various civil society organizations and academician United Nation, 2018). 


\section{Malaysian E-Participation Policy and Initiatives}

As Hummel (2016) stressed that the government need a tools and mechanism in supporting the e-participation, Malaysia also put the effort in implementing e-participation through various initiatives. Even though Malaysia is lagging from the developed countries, but we should give credit to the government for their hard work. Focusing on the e-participation in Malaysia, through the examination on various websites of the governmental department, the e-participation policy that have been represented is literally the same. According to Malaysia Administrative Modernization and Management Planning Unit (MAMPU) the e-participation policy in Malaysia aims to uphold the value of transparency in public participation and improve the quality of services by the government through e-participation practices. The government realize public involvement in the government helps the government to have a broader perspectives, various input and information as well as potential solutions towards improving the outcomes of the services. It also helps to provide a productive relationship, a better communication and deliberation process and much more systematic governance (MAMPU, 2019a).

The government purposely invested in e-participation aims to open the opportunity for the public to easily involve in the policy and decision making processes in the government through the utilization of information and communication technologies. Among the communication channels that used by the government are Portal Poll; Public Participation; Portal Feedback that includes feedback, questions, complaints and suggestions; Customer Satisfaction Survey and Social Media such as Facebook, Twitter, Instagram and YouTube. Public are encouraged by the government to participate. However, the participation should be within the term and conditions that have been outlined in the e-participation policy as follows:

- Participant are strictly prohibited in making any provocative statements regarding the issues of racial, religion and politics.

- Participant are strictly prohibited in making any statement that degrading, attacking or offended other participants.

- Participant should use a proper language in making the statement to avoid any offensive issues and be open minded to other participant's opinion.

- Participant should give the opinion within the issues that have been discussed.

- Participant are strictly prohibited to discuss or connect in any pornographic website.

- Participant should not make any statement that breach the copyright of law, trademark and patent.

- Participant are prohibited in using this platform either commercially or otherwise to hold any contest or run any business by taking other participant's money through various fraud schemes.

- Participant should not provide any software or computer programs that may harm to other participant's computer and should also be aware that any uploaded files are not contaminated by any viruses.

- The participant individually should understand that they are responsible to bear the risk on any statement that been given in the e-Inclusion room because administrator in any situation does not have the responsibility to approve, favour or confirm the truth, accuracy or reliability of any statement made.

- The administrator of the e-Inclusion at any time even in the absence of the author's consent have the right modify or remove any statement or comment. 
- The administrator of the e-Inclusion at any time without any $\mathrm{n}$ have right to modify the Investment Policies and Guidelines on e-Inclusion at any time without prior announcement or notice.

- Participants are encouraged to obey with the terms and conditions that stipulated in the e-Inclusion Guidelines (MAMPU, 2019a).

Besides the e-participation policy, the government shown that they are serious in promoting e-participation through various initiatives and programme such as:

\section{Malaysia Internet Centre}

According to Malaysian Communications and Multimedia Commission (MCMC) (2014a) the 1Malaysia Internet Centre that was initially built in 2007 is one of the oldest projects under the Universal Service Provision. It is one of the initiatives that intentionally to bring the positive impact on the social and economic of the community. This centre was provided with the all the necessary equipment such as desktop computers, printer, projector and screen. Additionally, it is not only providing basic internet access to the community, but training on the ICT also was given by two supervisors that employed fulltime at the centre. The objective of this centre is to provide up to $4 \mathrm{Mbps}$ basic Internet access to the rural and isolated areas where there are no internet facilities. Currently, there are 678 centres that operating throughout the state.

\section{Malaysia Internet Centre for the Urban Poor}

1Malaysia Internet Centre for the urban poor that started in 2013 is a program that expended from the 1Malaysia Internet Centre. Specifically, it aims to provide an affordable basic internet access available to the poor and underserved people in urban areas. There are 100 centres are expected to be built in urban-low-cost public housing projects by 2015 . This centre is administered by two permanent employed staff, equipped with all the basic facilities such as computers, printer, projector and screen as well as an access of the internet along with the training on the ICT (Malaysian Communication and Multimedia Commission, 2014a).

\section{Community WIFI}

Community WIFI provide the wireless internet access to the selected location in underserved areas. The objective of this initiative is to bring wireless internet access to all small communities in the remote villages right at their doorsteps. Focuses only on the selected village in remote areas, currently this programme successfully connected total of 4,270 villages with the wireless internet (Malaysian Communication and Multimedia Commission, 2014b).

\section{i-Tegur}

i-Tegur or formerly known as iKepoh, is an initiative developed by the ministry to facilitate the public in making the complaints to the local authorities (PBT) through mobile application. i-Tegur was developed purposely to give the best service to the public and to create a good relationship between the PBT and the citizens through a user-friendly channel. Through this channel, public could easily send their complaints whereas the government could manage and monitoring the complaint effectively. This application also helps the top management of the PBT and Ministry of Urban Wellbeing, Housing and Local Government (KPKT) to simply access to public complaints through the same resources. i-Tegur play the important function for the public to send their complaint through mobile without physical constraint. It also very responsive in providing the feedback as well as in monitoring the local authority's complaint's statistic efficiently (KPKT, 2018). 


\section{Jom Sembang}

Other initiative is the establishment of Jom Sembang or formerly recognized as Digital Government Lab. Jom Sembang is a collaboration effort between Malaysia Digital Economy Corporation (MDEC) with other members of the Digital Government Technical Working Group (DGTWG) which consists of the MCMC, MAMPU, Malaysia's Performance Management and Delivery Unit (PEMANDU), Economic Planning Unit (EPU) and Public Service Department (JPA). This platform aims to offer a continuous involvement for the citizen and stakeholders on the topic related to the Digital Government initiatives. The objective of this initiatives is to address the citizens needs through three basic principle namely conversation, consultation and communication. Jom Sembang could be organised either in physical location or through the digital platform (MAMPU, 2019b).

One of the physical examples of Jom Sembang programme is on the 5 Mobile App Idea that was held on September 28 and October 5, 2015 at Putrajaya IOI Marriot and MAEPS Serdang respectively. The discussion was developed by the Immersion participants from the Immersion programme that consisted of 15 government's officers. The government aim that through this program, an inventive Citizen Centric Mobile App could be developed in serving the needs and demand of the citizens in much transformative ways. Headed by MAMPU, this programme also gets the collaborative involvement of other agencies includes MDEC, JPA and National Institute of Public Administration (INTAN) Meanwhile, the digital example of Jom Sembang was the enhancement of the Provider-Based Evaluation (ProBE) system in 2016. ProBE that annually self-evaluate the government agencies websites was rebranding from the Malaysia Government Portals and Websites Assessment (MGPWA). Through this virtual platform, users were able to provide their inputs and feedback towards the system enhancement. There were approximately 20 users participated in this online discussion. They are the webmasters from various government agencies. Thus, MDEC is currently developing the new enhanced ProBE system based on the users' needs (MAMPU, 2019b). However, the link to this initiative currently is no longer available.

\section{Discussion and Conclusion}

This paper offers straightforward examination on the policy and practical initiatives on eparticipation implementation in Malaysia. This paper also highlighted the initiatives that took place across various countries and deliberates the implementation of e-participation among top performers as a desirable model for Malaysia. It is shown that Malaysia had tremendous efforts in supporting e-participation implementation. Even though e-participation medium in Malaysia is not as advanced as what other countries had and there is still a lot to improve, nevertheless the government effort toward e-participation should been acknowledge. Hence, the successful implementation of e-participation on other countries could be an example to Malaysia. Through the initiatives it shown that Malaysia had tried to narrow the digital gap between the society by providing the computer and internet facilities to the rural area. However, computer and internet facilities may not be useful without public awareness. The level of awareness and understanding among Malaysian might be low compare to the people in develop countries. As a top leading country in e-participation, Denmark have the strategy to make all the people in Denmark is ready for the digital transformation through education and training. We believe that this is one of the key values of the Denmark's achievement that Malaysia are lacking. We have noticed that we stressed on the supply side such as skilled and educated government's administrator in e-participation. However, we might neglect the demand side which is our people as our customer to be served whether they have the knowledge, skills and ability to utilise all the digitalise facilities that have been provided. 
In brief, the successful implementation of e-participation requires a clear-cut process with a good design of legislation, policies and strategy. However, a strong enforcement also is one of the important values that should not be neglected. Moreover, besides other important aspect such as the government capacity in term of technical, financial, administrative and political, the government willingness to adopt the e-participation is the top among others. The willingness and determination of the government will shape the determination, direction and action that want to be achieved. As Arstein portrayed in her theory that participation as a hierarchical transformational proses in the government, however it is proved that there is no absolute hierarchy to involve the public. Either participation take place at the highest or lowest level of government through traditional or online form, it is totally depend the government. Denmark for example, by making electronic interaction as a mandatory aspect in most part of their lives, therefore it is unquestionably Denmark had proved that their determination is the key factor why they are always on the top of others. Therefore, making the e-participation a reality rather than conceptual only, is not easy and it does not happen overnight because it takes everything such as time, money, system, infrastructure and effort and hard work from various stakeholders to make it work.

Above and beyond, although this study descriptively discusses on e-participation policy and initiatives in Malaysia with the experience of the world best leader Denmark and Finland without any in-depth critical argument in the discussed element, we hope it provide useful insight, knowledge and understanding to the reader. Therefore, the future study would be very much valuable if it could expansively and exhaustively explore every aspects of the successful implementation in others top leading countries. This is because, we noticed that there is so much to learn and discover on the successful initiatives in Denmark and Finland for example that we might not have a chance to address. Additionally, the real challenges aspect of the successful e-participation could also be comprehensively explored so that it could facilitate the understanding of this subject matter in a better way.

\section{References}

Agency for Digitisation (2016). A stronger and more secure digital Denmark: The Digital Strategy 2016-2020. Copenhagen: Danish Ministry of Finance, Local Government Denmark and Danish Regions. Retrieved from https://en.digst.dk/media/14143/ds_single page_uk_web.pdf

Arnstein, S. R. (1969). A ladder of citizen participation. Journal of the American Institute of Planners, 35(4), 216-224.

Chee Wei Phang \& Atreyi Kankanhalli. (2008). A framework of ICT exploitation for eparticipation initiatives. In Communication of the ACM, 52(12), 128-132.

Chia Jie Lin (2018). Denmark leads the world in digital government. Retrieved from https://govinsider.asia/innovation/denmark-online-services-digital-government-australiakorea/

Government Europa (2018, 14 May). Digital post and the digitisation of society in Denmark. Retrieved from https://www.governmenteuropa.eu/digital-post-digitisation-denmark/873 89/

Hochtl, J., Parycek, P., \& Sachs, M. (2011). E-participation readiness of Austrian Municipalities. Transforming Government: People, Process and Policy, 5(1), 32-44.

Holkeri, K. (2002). Public scrutiny and access to information in Finland. In OECD, Public sector transparency and accountability: Making it happen (pp. 151-196). Paris: Organization for Economic Co-operation and Development.

Hummel, D. (2016). Shrinking cities and the possibilities of e-participation. National Civic Review, 8-12. 
Kim, S. \& Lee, J. (2012) E-Participation, Transparency, and Trust in Local Government. Public Administration Review, 72(6), 819-828.

King, C. S., Feltey, K. M., \& Susel, B. O. (1998). The question of participation: Toward authentic public participation in public administration. Public Administration Review, 58(4), 317-326.

KPKT. (2018). i-Tegur. Retrieved from https://i-tegur.kpkt.gov.my/

Kubicek, H. \& Aichholzer, G. (2016). Chapter 2: Closing the evaluation gap in eparticipation research and practice. In G. Aichholzer, H. Kubicek \& L. Torres (Eds.), Evaluating e-participation: Framework, Practice, Evidence (Public Administration and Information Technology, Vol. 19, pp. 11-45). Switzerland: Springer International Publishing.

Macintosh, A. (2004). Characterizing e-participation in policy-making. In System Sciences 2004: Proceedings of the 37th Annual Hawaii International Conference (pp. 117-126). New York: IEEE.

Malaysian Communication and Multimedia Commission. (2014a). 1Malaysia Internet Centre. Retrieved from http://usp.skmm.gov.my/Projects/1Malaysia-Internet-Centre.aspx

Malaysian Communication and Multimedia Commission. (2014b). Community WIFI. Retrieved from http://usp.skmm.gov.my/Projects/Wireless-Village.aspx

MAMPU. (2019a). E-participation policy. Retrieved from https://malaysia.gov.my/portal/ content $/ 30042$

MAMPU. (2019b). E-participation: Jom Sembang. Retrieved from https://www.malaysia. gov.my/portal/content/30043

Mohamad Aizi Salamat, Shahizan Hassan \& Mohamad Syakiran Muhammad. (2011a). Electronic participation in Malaysia. Journal of e-Government Studies and Best Practices, 2011, 1-11.

Mohamad Aizi Salamat, Shahizan Hassan \& Mohamad Syakiran Muhammad. (2011b). An Actor-Network Theory (ANT) approach to Malaysian e-participation framework. International Conference on Social Science and Humanity (pp. 83-88). Singapore:

Mohamad Aizi Salamat, Shahizan Hassan, Mohd Farhan Md Fudzee \& Azizul Azhar Ramli. (2012). A framework for formulating Malaysia's public policy through citizen eparticipation. Retrieved from http://www.kmice.cms.net.my/ProcKMICe/KMICe_2012/ PDF/CR73.pdf

Nachmias, D., \& Rotem, A. (2007). E-Participation in Israeli local governments: A comparative analysis. In D. Remenyi (Ed.), Proceedings of the $7^{\text {th }}$ European Conference on e-Government: ECEG 2007 (pp.367-384). United Kingdom: Academic Conferences Ltd.

Nagel, T. (1995). Equality and partiality. New York: Oxford University Press.

Nur Rusydina Khadzali \& Zainal Md. Zan. (2018). E-participation: A systematic understanding on public participation in the government in $21^{\text {st }}$ century. Jurnal Intelek, 13(2), 29-46.

Pratchett, L., Durose, C., Lowndes, V., Smith, G., Stoker, G., \& Wales, C. (2009). Empowering communities to influence local decision making: A systematic review of the evidence. London: Department for Communities and Local Government. Retrieved from http://www.ict-21.ch/com-ict/IMG/pdf/1241955Empowering-communities\%20to-influen ce-local-decision-making.pdf

Panopoulou, E., Tambouris, E., Nielsen, E. S., Zotou, M., \& Tabaranis, K. (2011). Learning from eparticipation initiatives of regional and local level authorities in Greece and Spain. Journal of Balkan and Near Eastern Studies, 13(1), 77-96. 
Perez, D. D. (2015). Denmark has made digital mandatory for government-citizen interactions. Retrieved from https://diginomica.com/denmark-has-made-digital-manda tory-for-government-citizen-interactions

Sæbø, Ø., Rose, J., \& Flak, L. S. (2008). The shape of eParticipation: Characterizing an emerging research area. Government Information Quarterly, 25, 400-428.

Sobaci, Z. (2010). What the Turkish parliamentary web site offers to citizens in terms of eparticipation: A content analysis. Information Polity, 15, 227-241.

Tambouris, E., Liotas, N., Kaliviotis, D., \& Tarabanis, K. (2007). A framework for scoping eParticipation. In J. B. Cushing, \& T. A. Pardo (Eds.), Proceedings of the 8th Annual International Conference on Digital Government Research (pp. 288-289). Philadelphia, PA: Digital Government Research Center.

United Nation. (2016). United Nations Survey 2016: E-government in support of sustainable development. Retrieved from https://publicadministration.un.org/egovkb/en-us/Reports/ UN-E-Government-Survey-2016

United Nation. (2018). United Nations Survey 2018: Gearing e-government to support transformation towards sustainable and resilient societies. Retrieved from https://publicadministration.un.org/egovkb/en-us/Reports/UN-E-Government-Survey2018

Wallace, C., \& Pichler, F. (2009). More participation, happier society? A comparative study of civil society and the quality of life. Social Indicators Research, 93, 255-274.

Wilhelmsson, N. (2017). eDemocracy in Europe (pp. 20-104). In Pohoryles, R. \& Decheva, R (Eds), eDemocracy and eParticipation: The precious first steps and the way forward. Europe: European Liberal Forum.

Wirtz, B., W., Daiser, P., \& Binkowska, B. (2016). Eparticipation: A strategic framework. International Journal of Public Administration, 41(1), 1-12. 